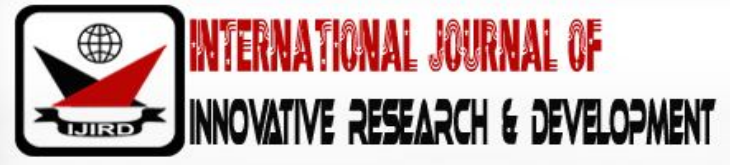

ISSN 2278 - 0211 (Online)

\section{Amerliorative Effect of Vernonia Amygdalina in Dexamethasone Induced Hyperglycaemia}

Christian Onahinon
Co-Researcher, Department of Human Physiology, Benue State University, Makurdi, Nigeria
Dr. Julie Ibu
Chief Inspector, National Youth Service Corps, Nigeria
Dr. Nndunno Akwaras
Senior Registrar, Federal Medical Centre, Makurdi, Nigeria
Dr. Emmanuel Eru
Dr. Adugba Augustine
Lecturer, Department of Physiology, Benue State University, Makurdi, Nigeria
Lecturer, Department of Physiology, Benue State University, Makurdi, Nigeria
Samuel Odeh
Lecturer, Department of Physiology, Benue State University, Makurdi, Nigeria
John Ibu
Lecturer, Department of Physiology, Benue State University, Makurdi, Nigeria

\section{Abstract:}

Hyperglycaemia has been found to be one of the main side effects associated with dexamethasone administration. Vernonia amygdalina(VA)-bitter leave is a common shrub consumed in Nigeria. This study was carried out to investigate the ameliorative effect of vernonia amygdalina on dexamethasone induced hyperglycaemia. Twenty (20) adult Wistar albino rats of both sexes weighing 200-250g were randomly allocated into four (4) groups with five (5)animals per group. Group 1 was given normal saline without inducing hyperglycaemia in the group to serve as normoglycaemic control. Animals in group 2, group 3 and group 4 were given prestandardised dose of $1 \mathrm{mg} / \mathrm{kg}$ body weight dexamethasone for seven days according to the method of Ghaisas et al., 2009. After induction of hyperglycemia, group 2 were given a daily dose of $1 \mathrm{mg} / \mathrm{kg}$ body weight of dexamethasone with normal saline, group 3., daily dose of $1 \mathrm{mg} / \mathrm{kg}$ body weight of dexamethasone with $100 \mathrm{mg} / \mathrm{kg}$ body weight of VA and group 4 daily dose of $1 \mathrm{mg} / \mathrm{kg}$ body weight of dexamethasone with $200 \mathrm{mg} / \mathrm{kg}$ body weight of VA. The result showed that the fasting blood glucose of group 1 was $81 \pm 2.8 \mathrm{mg} / \mathrm{dl}$. The fast blood glucose of group 2 was $137 \pm 15.4$ vs $156 \pm 20.3 \mathrm{mg} / \mathrm{dl}$, group 3 was $129 \pm 9.7 \mathrm{vs} 90 \pm 2.7 \mathrm{mg} / \mathrm{dl}$ and group 4 was $126 \pm 7.3 \mathrm{vs} 86 \pm 4.2 \mathrm{mg} / \mathrm{dl}$. There was a significant difference in the fasting blood glucose of group 1compared to group 2, group 3 and group $4(\mathrm{p}<0.01)$ after induction of hyperglycaemia $(p<0.01)$. There was no significant difference between group 1 and group3, group1 and group $4(p>0.05)$ after VA was co administered with dexamethasone. This shows that Vernonia amygdalina ameliorate dexamethasone induced hyperglycaemia.

Keywords: Vernonia amygdalina, dexamethasone induced hyglycaemia, fasting blood glucose

\section{Introduction}

Diabetes mellitus one of the most common non-communicable diseases globally (IDF, 2013) is a complex and chronic metabolic disorder characterized by a sustained hyperglycaemia with a fasting blood glucose $\geq 126 \mathrm{mg} / \mathrm{dl}$, with disturbances of carbohydrate, fat, protein metabolism, high oxidative stress induced by the generation of highly reactive free radicals (Sharma et al.,2010) which result from defects in insulin secretion, insulin action, or both (Kjems et al., 2001). Non insulin dependent diabetes mellitus accounts for more than $90 \%$ of diabetic population. The aetiology of type 2 diabetes mellitus in which the b-cells of pancreas are usually functional, very often involves hormonal imbalance (Roith et al., 2000). Hormones such as catecholamine, glucagon, cortisol and thyroxin, either through directly or through their influence on other hormones, affect carbohydrate metabolism to elevate blood glucose level leading to insulin resistance. Insulin resistance has been shown to be present in conditions like Type-II Diabetes, obesity and dyslipidemia. In fact, the hormones of the adrenal cortex are well 
known for their diabetogenic effects and are responsible for most steroid diabetes (Gholap and Kar.,2003). Dexamethasone is a synthetic glucocorticoid with anti-inflammatory and immunosuppressant properties. However, long-term use of dexamethasone results in deleterious side effects such as hyperglycemia, hepatosteatosis, and insulin resistance (Vegiopoulos and Herzig., 2007). With these drawback, strategy to achieve therapeutic effect of dexamethasone without its hyperglyceamic adverse effects could be to combine the administration of a dexamethasone with another agent (not targeting glucocorticoid receptor) that can mitigate the gluconeogenic side effects of dexamethasone without altering its therapeutic activity. Also, due to the etiopathogenesis of diabetes mellitus, harmful side effects of synthetic drugs, the inability of existing modern therapies to control all the pathological aspects of the diabetic disorder, enormous cost of modern drugs as well as the poor availability of the advanced therapies for many rural populations in developing countries (Tanaka et al., 1992), alternative strategies to current pharmacotherapy of diabetes mellitus are urgently needed. Currently, available therapies for diabetes include "insulins, insulin secretagogues (sulfonylureas, meglitinides), insulin sensitizers (biguanides, thiazolidinedione), agents that enhance incretin secretion and action (incretin analogues, incretin mimetics, dipeptidyl peptidase IV (DPP-IV) inhibitors), agents that decrease gastrointestinal glucose absorption (alpha glucosidase inhibitors, alpha amylase inhibitors, sodiumglucose co-transporter (SGLT-1) selective inhibitors), agents that promote renal glucose excretion (sodium-glucose cotransporter (SGLT-2) inhibitors) and others (amylin analogue, bile acid sequesterants, bromocriptine) (Verspohl, 2012).

Presently, there is growing interest in herbal remedies due to the multimodal approach required in the management of diabetes mellitus couple with the cost, non availability, side effects associated with the oral hypoglycemic agents (Tiwari and Rao, 2002). Ethnobotanical and ethnopharmacological surveys report that more than 1200 plants are being used in many ethnic societies around the world in traditional medicine for their alleged hypoglycemic activity (Akah et al.,2002) and Vernonia amygdalina is one of them and could attenuate dexamethasone induced hyperglycaemia.

\section{Materials and Method}

Fresh leaves of V. amygdalina were collected from the natural habitat in Makurdi, Benue State, Nigeria. The leaves were confirmed by a taxonomist from the Department of Botany in the Faculty of Science, Benue State University and was allocated a voucher number and deposited in the herbarium of the department.

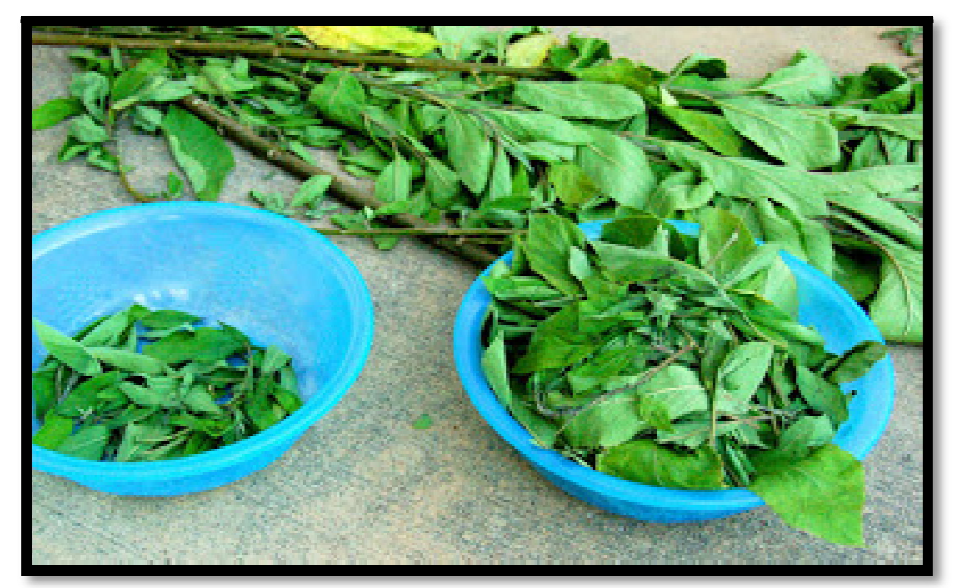

Figure 1: Leaves of Vernonia Amygdalina Used in the Study

\subsection{Preparation of Extract}

The leaves were sorted out to obtain only the fresh leaves and washed with distilled water without squeezing to remove debris and dust particles. They were shade dried for ten days and then, the dried leaves were pulverized with LG electric grinding machine. A portion, $(600 \mathrm{~g})$ of the powdered leaves was soaked in $2400 \mathrm{ml}$ of $70 \%$ ethanol for 72 hours with the solution thoroughly stirred twice daily. The extracts were then be filtered with WHATMAN no1 filter paper. The filtrate was air dried and then reconstituted with distill water later.

\subsubsection{Chemicals}

Dexamethasone injection (Alpha pharmaceutical LTD)

\subsubsection{Animals}

Adult albino rats of Wister strain weighing 200-250g of either sex was purchased from the disease-free stock of the animal house of the College of Health Sciences, Benue State University, Makurdi and used for the study. They were maintained in normal and standard laboratory conditions of temperature $28^{\circ} \mathrm{C}$ and relative humidity (with 12-hour light dark cycle) and adequate ventilation. The animals were fed with commercial diet (Vital Feed Nig.Ltd.) and water ad libitum. Food was withheld 8 hours before the experiments, but they had free access to water. Permission for the use of animals and animal protocols were obtained from the Animal Ethics Committee of Benue State University Makurdi, prior to the experimentation. 


\subsubsection{Animal Categorization}

The animals were allowed 14-day acclimatization period, after which they were randomly allocated into four groups of 4 rats per group: $(n=5)$

Induction of hyperglycemia.

Hyperglycaemia was also be induced in group 2-4 by daily administration of a prestandardized dose of dexamethasone (1 $\mathrm{mg} / \mathrm{kg}$ ) for 7 consecutive days (Ghaisas et al., 2009). Then group 2, 3 and 4 received continuous dose of dexamethasone with extract and/ or placebos.

\subsubsection{Animal Grouping and Experimental Design}

The animals were randomly allocated into 4 groups $(n=5)$

Group 1 normoglycaemic control

Group 2 continuous daily dose of $1 \mathrm{mg} / \mathrm{kg}+$ normal saline

Group 3 continuous daily dose of $1 \mathrm{mg} / \mathrm{kg}+100 \mathrm{mg} / \mathrm{kg}$ of VA

Group 4 continuous daily dose of $1 \mathrm{mg} / \mathrm{kg}+200 \mathrm{mg}$

\section{Results}

\begin{tabular}{|c|c|c|c|c|}
\hline Group & $\begin{array}{c}\text { Before } \\
\text { Dexamethasone } \\
\text { FBS } \pm \text { SEM } \\
\text { (Mg/ / Dl) }\end{array}$ & $\begin{array}{c}\text { 7days After } \\
\text { Dexamethasone } \\
\text { FBS } \pm \text { SEM } \\
\mathbf{( M g} / \mathbf{D l})\end{array}$ & $\begin{array}{c}\text { After } \\
\text { N.Saline/ VA } \\
\text { FBS } \pm \text { SEM } \\
\text { (Mg/ Dl) }\end{array}$ & \% Change FBS \\
\hline 1 & $81 \pm 2.8$ & - & - & - \\
\hline 2 & $73 \pm 2.6$ & $137 \pm 15.4$ & $156 \pm 20.3$ & $13.9 \%$ \\
\hline 3 & $77 \pm 4.1$ & $129 \pm 9.7$ & $90 \pm 2.7$ & $-25.6 \%$ \\
\hline 4 & $77 \pm 2.4$ & $126 \pm 7.3$ & $86 \pm 4.2$ & $-31.8 \%$ \\
\hline
\end{tabular}

Table 1: Fasting Blood Glucose of Wistar Albino Rats before and 7 Days after Givin Dexamethas One and 14days after Giving Dexamethasone with Normal Saline/ Va Extract

Table 1 shows the fasting blood glucose of wistar albino rats before administration of dexamethasone. The fasting blood glucose of the rats used falls within physiological range and there was no significant difference within and between groups as shown in table 2 (Levene test of homogeneity) $p>0.05$ Table 1 also showed the fasting blood glucose of the rats after they were given $1 \mathrm{mg} / \mathrm{kg}$ body weight of dexamethsone. There was a significant increase in the fasting blood glucose of the rats $(p<0.05)$. After induction of hyperglycaemia, there was no significant difference in homogeneity of variance $(p>0.05)$.

Table 1 also showed the fasting blood glucose of the hyperglycaemic rats after receiving dexamethasone with normal saline/ VA extract.

\begin{tabular}{|c|c|c|c|c|}
\hline \multicolumn{5}{|c|}{ Test of Homogeneity of Variances } \\
\hline & $\begin{array}{c}\text { Levene } \\
\text { Statistic }\end{array}$ & df1 & df2 & Sig. \\
\hline FBS before Dex & 1.021 & 3 & 16 & .410 \\
\hline FBS after dex & 1.700 & 3 & 16 & .207 \\
\hline
\end{tabular}

Table 2: Test of Homogeneity of Variances

Table 2 Levene test of homogeneity of Variance in the fasting blood glucose before administration of $1 \mathrm{mg} / \mathrm{kg}$ body weight of dexamethas one and 7days after daily administration of dexamethas one. There was not significant difference in homogeneity before and after induction of hyperglycaemia.

\begin{tabular}{|c|c|c|c|c|c|}
\hline \multicolumn{7}{|c|}{ ANOVA } \\
\hline & $\begin{array}{c}\text { Sum of } \\
\text { Squares }\end{array}$ & $\mathrm{df}$ & Mean Square & $\mathrm{F}$ & Sig. \\
\hline Between Groups & 18941.600 & 3 & 6313.867 & 11.439 & .000 \\
\hline Within Groups & 8831.600 & 16 & 551.975 & & \\
\hline Total & 27773.200 & 19 & & & \\
\hline
\end{tabular}

Table 3: Analysis Of Variance after Giving Dexamethasone Induced Hyperglycaemic Wistar Abino

Rats Co-Administration of Dexamethasone with Normal Saline/ Va Extract 
From table 3, there was a significant difference in the fasting blood glucose between group 2,3 and $4(\mathrm{p}<0.01)$. Turkey Post Hoc test was used to determine where the significant difference was.

\begin{tabular}{|c|c|c|c|c|}
\hline \multicolumn{5}{|c|}{$\begin{array}{c}\text { Homogeneous Subsets } \\
\text { FBS after DEX+AGENTS }\end{array}$} \\
\hline & \multirow{2}{*}{$\begin{array}{l}\text { Groups of Wistar albino } \\
\text { rats }\end{array}$} & \multirow[t]{2}{*}{$\mathrm{N}$} & \multicolumn{2}{|c|}{ Subset for alpha $=0.05$} \\
\hline & & & 1 & 2 \\
\hline \multirow[t]{5}{*}{ Tukey HSDa } & Normoglycemic control & 5 & 80.6000 & \\
\hline & $20 \mathrm{mg} / 100 \mathrm{~g} \mathrm{VA}$ & 5 & 86.2000 & \\
\hline & $10 \mathrm{mg} / 100 \mathrm{~g} \mathrm{VA}$ & 5 & 89.8000 & \\
\hline & Diabetic control & 5 & & 156.2000 \\
\hline & Sig. & & .924 & 1.000 \\
\hline
\end{tabular}

Table 4: Turkry Homogeneous Subsets of the Fasting Blood Glucose of Dexamethasone Induced Hyperglycaemic Wistar Abino Rats Co-Administration of Dexamethasone with Normal Saline/Va Extract

Means for Groups in Homogeneous Subsets Are Displayed

a. Uses Harmonic Mean Sample Size $=5.000$

From the table there was a significant difference between group 2 and group1, group 3 and group 4 ( $\mathrm{p}<0.01$ ). There was no significant difference in fasting blood glucose between group 1, group 3 and group 4 ( $\mathrm{p}>0.05)$

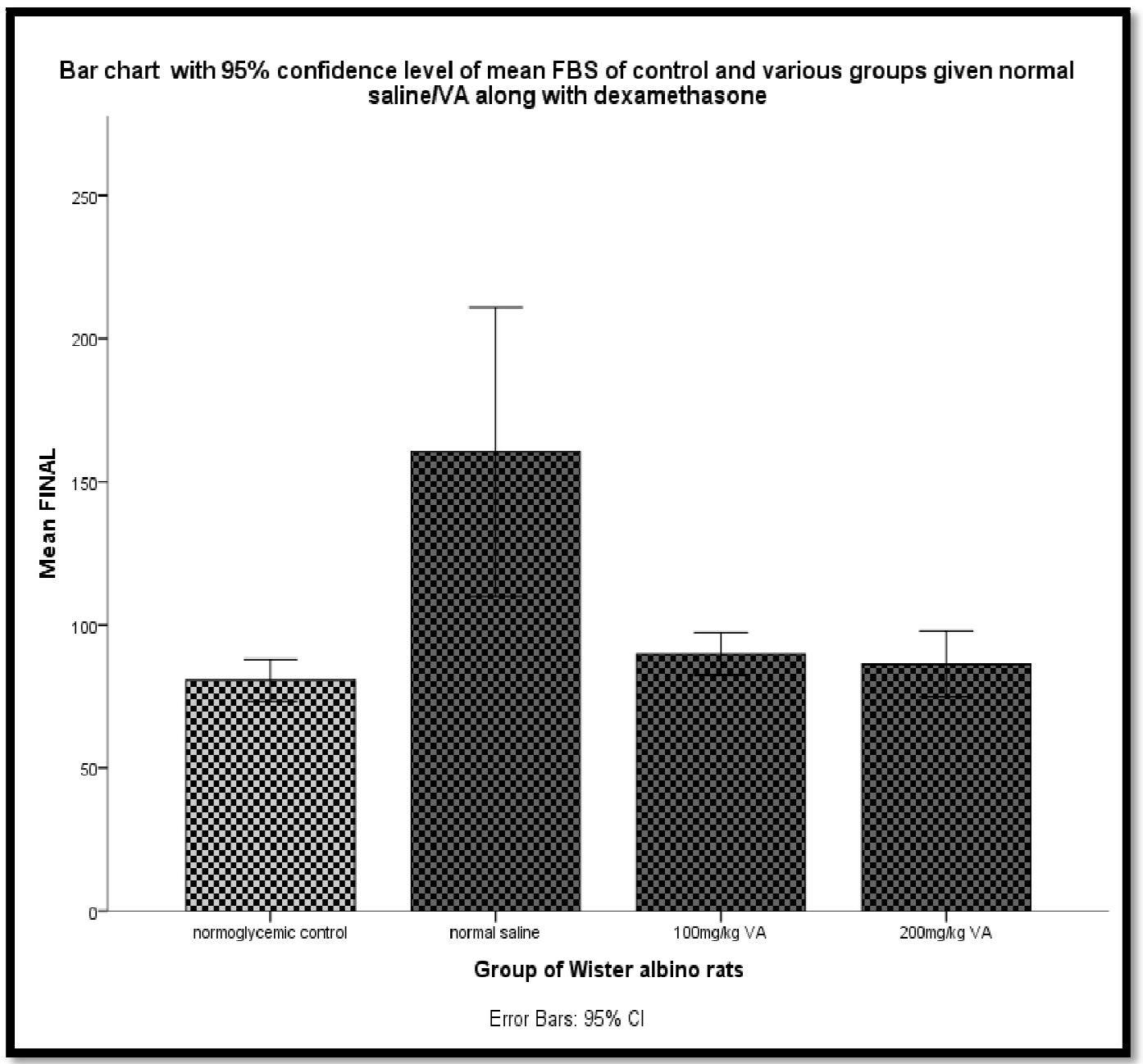

Figure 2

The bars in figure 2 showed the significant difference between the dexamethasone+normal saline group and dexamethasone $+10 \mathrm{mg} / 100 \mathrm{~g}$ VA group and dexamethasone+20mg/ $100 \mathrm{~g}$ VA group. 


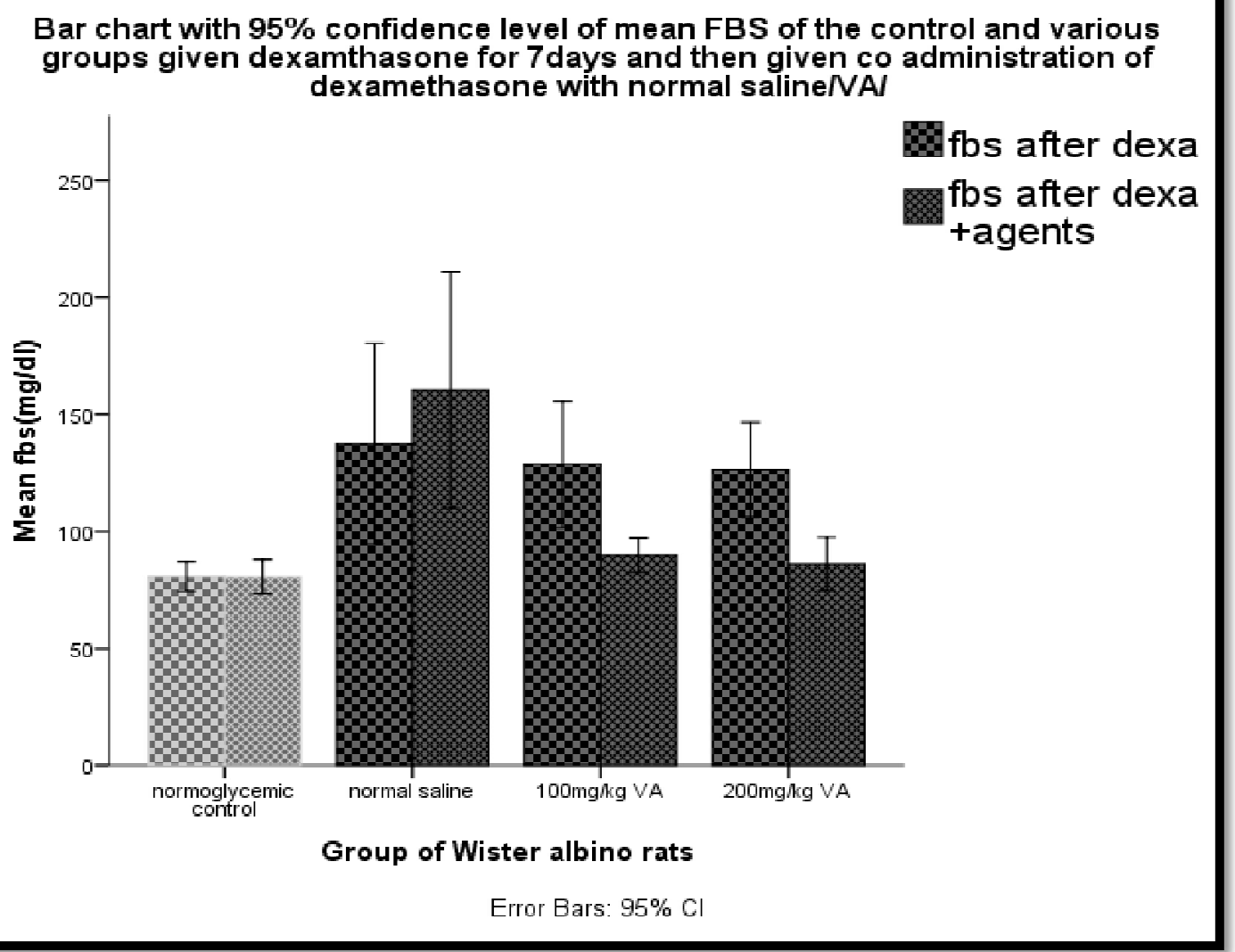

Figure 3

Figure 3 showed that there was further increase fasting blood glucose of the diabetic control group given normal saline. This implies that continuous administration of dexamethasone without appropriate antihyperglycaemic agent increases the fasting blood glucose.

Figure 3 shows that $10 \mathrm{mg} / 100 \mathrm{~g}$ VA and $20 \mathrm{mg} / 100 \mathrm{gVA}$ ameliorate the hyperglycaemic effect of dexamethasone. There was no significant difference between 10mg/ 100g VA and 20mg/100g VA ( $p>0.05)$.

\section{Discussion}

The result from this study showed that dexamethasone significantly increased fasting blood glucose of Wistar rats after seven (7) days ( $\mathrm{p}<0.01$ ). This was also reported by Gholap and Kar., 2005; Ghaisas et al., 2009. There was further increase in fasting blood glucose after 14days with continuous administration of dexamethasone which showed that administration of dexamethasone without appropriate agent to ameliorate its diabetogenic effect worsened insulin resistance .This agrees with the work of Robert et al.,1999 who demonstrated that Prolonged glucocorticoid exposure is associated with development of severe insulin resistance and metabolic dysfunction. Glucocorticoids have been shown to increase hepatic gluconeogenesis, decrease peripheral glucose uptake into muscle and adipose tissue, breakdown of muscle and fat to provide additional substrates for glucose production which is as a result of insulin resistance, caused by the alteration in binding of insulin to its receptor (receptor defect) or by the impairment of the intracellular response to insulin (post receptor defect) (Gholap \& Kar, 2005).

However, continuous co-administration of Vernonia amygdalina with dexamethasone to hyperglycaemic Wistar rats after 14 days resulted in a significant decrease in fasting blood glucose $(\mathrm{p}<0.01)$ and ameliorated dexamethasone induced hyperglycaemia. There was no significant difference between the euglycaemic group and the group given co- administration of dexamethasone with Vernonia amygdalina. There was no significant difference between $100 \mathrm{mg} / \mathrm{kg} \mathrm{VA}$ and $200 \mathrm{mg} / \mathrm{kg} \mathrm{VA}$ $(\mathrm{p}>0.05)$.

Vernonia amygdalina have been shown to possess antihyperglycamic effect (Akah et al., 2002). VA have also been shown to reverse oxidative stress imposed on pancreatic beta cell by alloxan (Owolabi et al.,2011). The ameliorating effects of VA in dexamethasone induced hyperglycaemia could be as a result of several active constituents that have been reported to be present in VA extract (Mukwaya et al., 2016). These phytochemicals include Saponins, Phenols, Tannins, Flavonoids, Terpenes and Glycosides (Mukwaya et al., 2016). It has been shown that flavonoids possess remarkable hypoglycaemic effect (Cazarolli et al., 2008). This effect has been linked to its ability to impair glucose absorption and improve glucose tolerance (Cazarolli et 
al., 2008). Flavonoid have also been shown to be potent antioxidant agent that impair the generation of free radicals (El-Abhar, and Schaalan, 2014).

Therefore, the result of this study indicates that Vernonia amydalina may serve as a prophylactic treatment of insulin resistance (the hallmark of type 2 diabetes) and may prevent the development of diabetes in prediabetic patients and prevents the development of secondary complications.

\section{References}

i. Akah P.A., Okoli C.O and Nwafor, S.V. (2002) Phytotherapy in the Management of Diabetes Mellitus. Journal of Natural Remedies, 2, 1-10

ii. Cazarolli, L.H., Zanatta, L., Alberton, E.H., Figueiredo, M.S., Folador, P., Damazio, R.G., Pizzolati, M.G. and Silva, F.R. (2008) Flavonoids: Cellular and Molecular Mechanism of Action in Glucose Homeostasis. Mini-Reviews in Medicinal Chemistry, 8, 1032-1038

iii. El-Abhar, H.S. and Schaalan, M. (2014) Phytotherapy in Diabetes: Review on Potential Mechanistic Perspectives and relative hyperglucagonemia in the minipig. Diabetes. 50:12

iv. Ghaisas M., Navghare V., Takawale A., Zope V., Tanwar M., Deshpande A (2009). Effect of Tectona grandis Linn. on dexamethasone induced insulin resistance in mice.J Ethnopharmacol 122: 304-307

v. Gholap S and Kar A (2003). Effects of Inula racemosa root and Gymnema sylvestre leaf extracts in the regulation of corticosteroid induced diabetes mellitus; involvement of thyroid hormones. Pharmazie; 58:413-5.

vi. Gholap S, Kar A (2005). Gymnemic acids from Gymnema sylvestre potentially regulates dexamethasone induced hyperglycemia in mice. Pharm Biol 43: 192-195.

vii. International Diabetes Federation (IDF) (2013). One Adult in ten will have Diabetes by 2030. [Online] Available http:/ / www.idf.org/ diabetesatlas.

viii. Kjems LL, Kirby BM, Welsh EM, Veldhuis JD, Straume M, McIntyre SS, Yang D, Lefebvre P, Butler PC. (2001) Decrease in beta-cell mass leads to impaired pulsatile insulin secretion, reduced postprandial hepatic insulin clearance World Journal of Diabetes, 5, 176-197

ix. Mukwaya Z, Engoru T, Kainza EJ, Inyani JK, Buligwanga S, Munanura EI, Kalidi R, Mugisha M, Adome , Anyama N, Kamba P, Kaggwa B (2016). Efficacy of A Syrup Formulated from Combined Extracts of Vernonia Amygdalina And Musa Paradisiaca For the Management of Type 2 Diabetes. African Journal of Pharmaceutical Research \& Development Vol. 8 No. 2; pp. 71-80

x. Owolabi M., Jaja S., Olatunji., OJa., Oyekanmi O., Adepoju S (2011). Attenuation of Oxidative Damage in Alloxan Induced Diabetic Rabbits Following Administration of the Extract of the Leaves of Vernonia amygdalina. Free Radicals and Antioxidants Vol 1, Issue 3, 94-101

xi. Robert C., Andrew S., Brian R., Walker (1999). Glucocorticoids and insulin resistance: old hormones, new targets. Clinical Science; 96:513-23.

xii. Roith D., Taylor S., Olefsky J (2000). Diabetes Mellitus: A Fundamental

xiii. and Clinical Text. Lippincott-Raven, Philadelphia, PA

xiv. Sharma VK, Kumar S, Patel HJ, Hugar S (2010). Hypoglycemic activity of Ficus glomerata in alloxan induced diabetic rats. International Journal of Pharmaceutical Sciences Review and Research 1(2):18-22

xv. Tanaka T, Tong HH, Xu Y, Ishimaru K, Nonaka G, Nishioka (1992). Tannins and related compounds: Isolation and characterization of three new ellagitannins, lagerstannins A, B and C, having a gluconic acid core, from Lagerstroemia speciosa (L.) Chem and Pharmaceu Bull Tokyo. 1992;40(11):2975-2980

xvi. Tiwari A K and Rao J M (2002) Diabetic mellitus and multiple therapeutic approaches of phytochemicals: Present status and future prospects. Curr. Sci. 83 30-37

xvii. Vegiopoulos A and Herzig S (2007). Glucocorticoids, metabolism and metabolic diseases. Mol Cell Endocrinol;275(12):43-61

xviii. Verspohl, E.J. (2012) Novel Pharmacological Approaches to the Treatment of Type 2 Diabetes. Pharmacological Reviews, 64, 188-237 